\title{
DEVELOPMENT OF THE COMPOSITION AND TECHNOLOGY OF A CARIES PREVENTIVE GEL
}

\author{
V.Yu.Anisimov, V.O.Gelmboldt, N.P.Polovko \\ Odessa National Medical University \\ National University of Pharmacy
}

Key words: caries preventive gel; cetylpyridinium hexafluorosilicate; technology of gels

Prevention of dental caries involves remineralization of the tooth surfaces with calcium and phosphorus medicines, but the use of fluorine-containing remedies in the form of a cream, gel and varnish is more effective. The aim of our work was to substantiate the composition and technology of a gel with cetylpyridinium hexafluorosilicate having the caries preventive action. A gelling agent - hydroxyethylcellulose that provides stability and the essential structural and mechanical properties of the gel has been selected experimentally. Microscopic studies have substantiated introduction of the solubilizer PEG-40 hydrogenated castor oil in the concentration of $0.5 \%$ that promotes dissolution of the peppermint essential oil with preserving the gel transparency. The use of $10 \%$ sorbitol has been substantiated to provide the moderate osmotic properties and to prevent the gel drying. Microbiological studies have shown the necessity of using sodium benzoate as a preservative in the concentration of $0.3 \%$. The temperature regimen of cetylpyridinium hexafluorosilicate introduction in the composition of the gel base has been substantiated by thermogravimetric studies. The technology of gel has been developed.

Local prevention of caries consisting in remineralization of the tooth surfaces provides the use of remedies containing calcium and phosphorus (solutions of calcium gluconate (2.5-10\%), calcium, and magnesium sulphate used on electrophoresis or as applications) [6].

Such drugs as "Belagel $\mathrm{Ca} / \mathrm{P}$ " (RF) available in the gel form that contains ions of calcium, potassium, sodium, magnesium, chlorine, phosphorus and "Remodent" (Ukraine) derived from the animal bone tissue containing ions of potassium, calcium, sodium, magnesium, manganese, iron, copper, zinc (used in the form of applications) also belong to this group of drugs.

Tooth Mousse GC (Japan) is in the form of a cream that contains casein phosphoric peptide and amorphous calcium phosphate. However, the predominant majority of drugs for prevention of dental caries contains fluorine [8]. These products are produced in the form of a gel, cream and varnish. Their nomenclature is presented by such gels as "Belagel F", Flioreks (Poland), Fluoridin gel (Germany) and varnishes - Belak (RF), Ftorlak (Ukraine), Flor-Oral (Germany), Ftoroplen (Ukraine), etc.

The necessity in effective prevention of caries and dominance of drugs of foreign production require the creation of effective and available caries preventive medicines.

\section{Materials and Methods}

Cetylpyridinium hexafluorosilicate with the caries preventive and mineralizing effect experimentally confirmed was selected as a caries preventive medicine synthesized at the premises of the Odesa National Medical University [7]. Gelling agents, hydrophilic non-aqueous solvents, solubilizers, preservatives permitted for use in cosmetic and dental products were used when developing the composition of the gel [2]. Organoleptic indices, thermal and colloidal stability, $\mathrm{pH}$ and the struc- tural and mechanical properties of the samples studied were determined. Colloidal stability was determined in a MPW-210 laboratory centrifuge (Poland) at the rate of $3000 \mathrm{rpm}$ for $5 \mathrm{~min}$. Thermostability was determined in a TC- $80 \mathrm{~m}-2$ thermostat at $(40 \pm 2)^{\circ} \mathrm{C}$ for $24 \mathrm{~h}$. The $\mathrm{pH}$ value was potentiometrically adjusted in $10 \%$ aqueous extraction on a $\mathrm{pH} 150 \mathrm{MI} \mathrm{pH}$-meter (RF).

Structural and mechanical parameters were determined on a Brookfield HB DV-II PRO rotary viscometer (USA) using a rotary type adapter with coaxial cylinders in the range of the shift speed gradient from 13.0 to $93.0 \mathrm{c}^{-1}$ at $20^{\circ} \mathrm{C}$. The kinetics of water absorption by the test samples of gels when introducing hydrophilic nonaqueous solvents was studied by dialysis through a semipermeable membrane at $34^{\circ} \mathrm{C}$ supported via a thermostat. A "Lumam-P1" bioluminescent microscope (Russia) with the magnifying power of 50 times was used for the visual study of the gel homogeneity. Receiving and processing of images were performed using the Scope Photo (version 3.0.12.498) software. The studies to substantiate the choice of the preservative were performed by the method of assessing the effectiveness of antimicrobial preservatives (SPhU 1.4 p.5.1.3) [2].

\section{Results and Discussion}

According to the results of the previous studies hydroxyethyl cellulose (HEC) in the concentration of 1.5$2.0 \%$ was selected as a gelling agent [1]. Since cetylpyridinium hexafluorosilicate (CPHFS) affects the viscosity indices of the gels obtained, namely reduces their structural viscosity (from 4480 to $3350 \mathrm{mPa}$ s to $1.5 \%$ and from 6180 to $5000 \mathrm{mPa}$ s to $2 \%$ ), it was necessary to conduct the study of gels within this concentration range. For this purpose, the sample with $1.75 \%$ HEC (rheograms of HEC gels from 1.5, 1.75 and 2.0\% gelling agent are shown in Fig. 1) was additionally pre- 


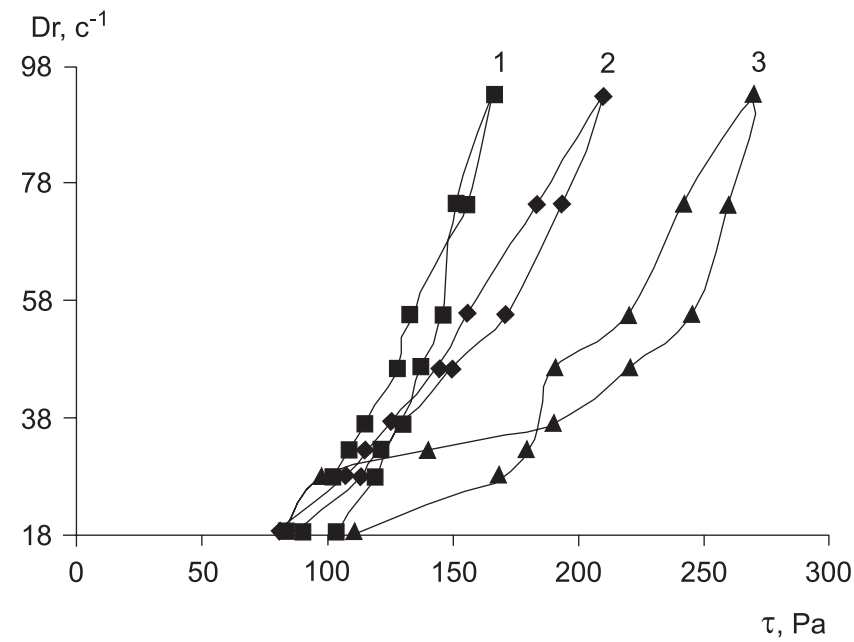

Fig. 1. The rheogram of dependence of the shift rate (Dr) on the shift stress $\left(\tau_{r}\right)$ of gels based on HEC where $1-1.5 ; 2-1.75 ; 3-2 \%$ gel.

pared. When introducing CPHFS the indices of the structural viscosity of $1.75 \%$ gel decrease from 5100 to $4800 \mathrm{mPa}$ s (at $20 \mathrm{C}$ and $20 \mathrm{rpm}$, it corresponds to the shift rate in $\left.\operatorname{Dr} 18.6 \mathrm{~s}^{-1}\right)$.

Since the gel with $1.75 \%$ HEC was the most satisfactory by the indices of the structural viscosity, this base was used to substantiate the composition of the caries protective gel.

Hydrophilic non-aqueous solvents are used in the composition of dental gels, they increase the solubility of drugs, contribute to their more complete and rapid release, and prevent the gel drying.

Considering the all abovementioned facts and in order to prevent the gel drying and improvement of organoleptic properties the hydrophilic nonaqueous solvents (HNS), such as $5 \%$ of glycerol and propylene glycol, and 5 and $10 \%$ of sorbitol ( $70 \%$ sorbitol solution) were introduced to the sample with $1.75 \%$ HEC [4]. By determining the osmotic activity it was found that all samples possessed the insignificant absorptivity, which increased with introduction of HNS in the range of sorbitol - glycerol propylene and was about $20-22,25$ and $33 \%$, respectively, compared to $16 \%$ gel base.

Taking into consideration the area of application, the low osmotic activity, which the product developed should have, as well as its taste characteristics, $10 \%$ sorbitol was selected as HNS.

The peppermint essential oil in the concentration of $0.5 \%$ previously solubilized was introduced into the gel composition to provide it with the cooling, deodorant and aromatizing effect. PEG-40 hydrogenated castor oil (PEG-40 HCO) was used as a solubilizer. Its optimal concentration was selected by microscopic analysis of the experimental samples containing $0.25 ; 0.5$ and $0.75 \%$ of the solubilizer.

The results of microscopic analysis (Fig. 3) have shown that introduction of $0.25 \%$ PEG- 40 HCO does not provide a complete dissolution of the essential oil. When increasing the content of solubilizer to $0.75 \%$ the homogeneous transparent gels are formed, it indicates the expediency of its introduction in the concentration of $0.5 \%$ since the higher content of a solubilizer is economically unreasonable.

When determining the $\mathrm{pH}$ value of the samples under research it has been found that it is within the range of 4.3-4.5. It is unacceptable for dental gels, which should

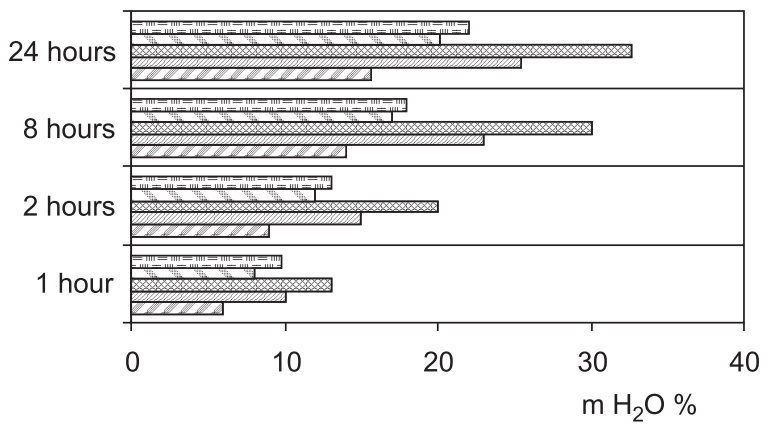

E A sample with $10 \%$ sorbitol

A sample with $5 \%$ sorbitol

A sample with propylene glucol

A sample with glycerol

A sample without PLR

Fig. 2. Kinetics of water absorption by the gels studied.

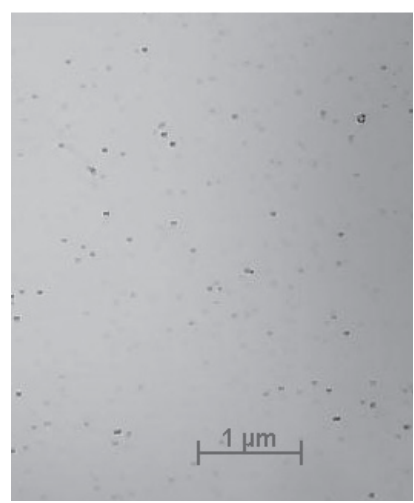

1

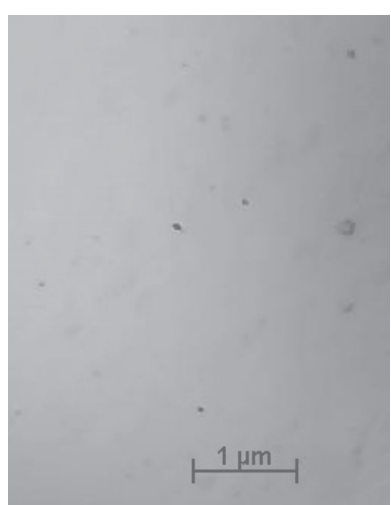

2

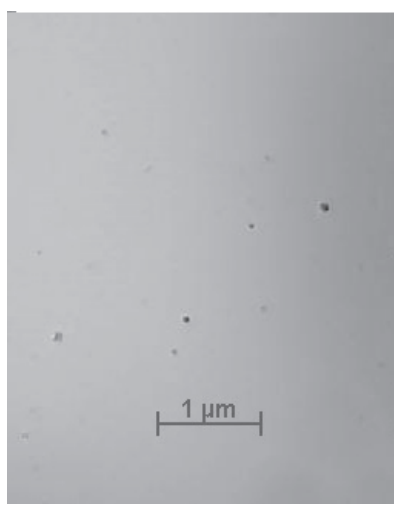

3

Fig. 3. Microscopy of the gel samples studied where 1 contains $0.25 \% ; 2-0.5 \% ; 3-0.75 \%$ GEG-40 hydrogenated castor oil. 


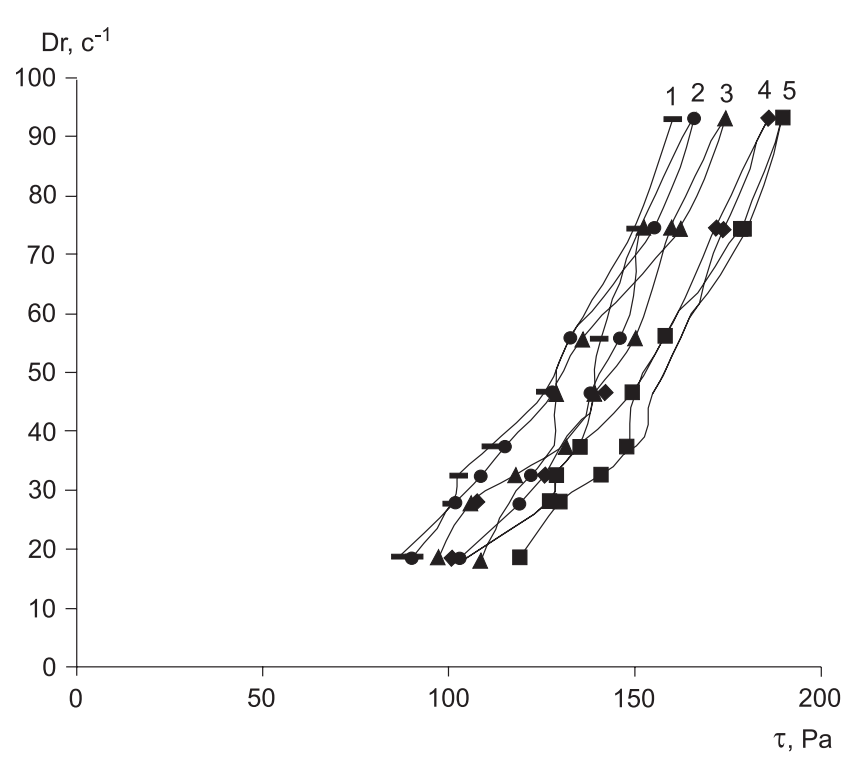

Fig. 4. The rheogram of dependence of the shift rate (Dr) on the shear stress $\left(\tau_{\mathrm{r}}\right)$ of $1.75 \% \mathrm{HEC}$ gel (Sample 4 ) when introducing: 1 - CPHFS; 2 - a complex of the substances mentioned; 3 - the solubilized peppermint essential oil; 5 - sorbitol.

have the $\mathrm{pH}$ value close to neutral. The $\mathrm{pH}$ value was adjusted by introduction of the phosphate buffer with $\mathrm{pH}$ 7.5.

It is known that both medicinal substances and a number of excipients can significantly affect the stability of gels, including their structural and mechanical properties $[5,9,10]$. The change of the rheological parameters was studied when introducing the ingredients selected into the gel base. Fig. 4 shows that introduction of CPHFS and the solubilized peppermint essential oil reduce the viscosity of the gel, and, on the contrary, introduction of propylene glycol increases while maintaining the type of flow and minor thixotropic properties.

To study the effectiveness of preservatives 6 samples were prepared. Sample 1 did not contain a preservative, Sample 2 contained $0.8 \%$ germaben, Sample 3 $0.3 \%$ nipagin, Sample $4-0.05 \%$ euxyl K, Sample 5 $1.0 \%$ euxyl PE 9010 , Sample $6-0.3 \%$ sodium benzoate; these substances were injected in Samples 2-6 in the con-

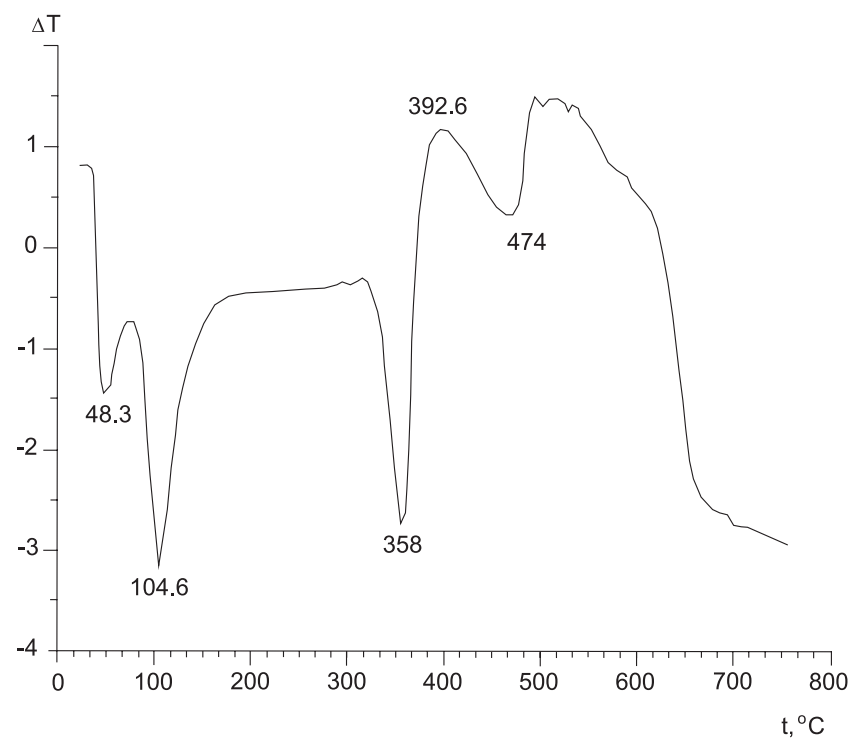

Fig. 5. The thermogram of cetylpyridinium hexafluorosilicate. centration recommended by the manufacturer. The method of assessing the effectiveness of antimicrobial preservatives (SPhU 1.4 p.5.1.3) was used in the research $[2,5]$. The method is based on introduction of a certain number of test-microorganisms in the samples under research and determination of their viability at regular intervals of time (for drugs for local application -2 days, 7, 14 and 28 days). The tests were taken from the infected samples after the time intervals specified, and the number of these microorganisms was identified in them. We used Staphylococcus aureus ATCC 6538, Pseudomonas aeruginosa ATCC 9027, Candida albicans ATCC 885-653, and Aspergillus brasiliensis ATCC 16404 as test-microorganisms according to the requirements of the SPhU. Determination of the logarithm value ( $\mathrm{lg})$ of reduction in the number of viable cells of microorganisms for the corresponding period of storage after contamination of the samples was the criterion for evaluating the effectiveness of antimicrobial preservatives.

The results given in Table show that after 2 days of storage of the inoculated samples the logarithm of reduction in the number of viable bacteria in Sample 1, without the preservative was over 2.0 and was equal to 2.27 for Staphylococcus aureus and 2.35 - for Pseudomonas aeruginosa. On the seventh day these indices were 3.74 and 4.16, respectively. On the 14-th day Staphylococcus aureus and Pseudomonas aeruginosa were not found. For the cells of Candida albicans fungi the logarithm of reduction in the number of viable cells was 3.5 on the 14-th day. For Aspergillus brasiliensis on the 14th day the logarithm reduction in the number of viable cells was 1.80 , and it was 1.95 on the 28 -th day. It does not correspond to the requirements of the SPhU.

Thus, the study of the sample without a preservative has shown that it does not correspond to the requirements of the SPhU by the indicator of the "antimicrobial effectiveness of preservatives" for drugs for external use and therefore, introduction of the preservative is necessary.

As a result of the studies of the effectiveness of antimicrobial preservatives in gel samples the following data were obtained (see Table): Sample 2 (gel $+0.8 \%$ germaben), Sample 3 (gel $+0.3 \%$ nipagin), Sample 4 (gel $+0.05 \%$ euxyl K 100), Sample 5 (gel $+1.0 \%$ euxyl PE 9010), Sample 6 (gel $+0.3 \%$ sodium benzoate) corresponded to criterion " $A$ " according to the requirements of the SPhU for drugs for external use.

Thus, it has been found that Samples $2-6$ are promising for the further work on creating a caries protective gel, however, by the totality of the requirements for preservatives and specificity of the composition and the effect of the gel the use of $0.3 \%$ sodium benzoate is the most rational. Besides the necessary antimicrobial activity the choice is stipulated by the fact that euxyl K 100, which contains benzyl alcohol, methylchloroisothiazolinone and methylisothiasolinone, is an effective preservative approved for use in the composition of medicinal cosmetic products, but according to new data it is not recommended in the products for mucous membranes, including toothpastes and dental gels, respec- 
The antimicrobial effectiveness of the preservatives in the gel samples studied

\begin{tabular}{|c|c|c|c|c|}
\hline \multirow[b]{2}{*}{ Exposition } & \multicolumn{4}{|c|}{ Lg of the initial microbial load reduction (SPhU requirements/sample) } \\
\hline & $\begin{array}{c}\text { Aspergillus brasiliensis } \\
\text { ATCC } 16404\end{array}$ & $\begin{array}{c}\text { Staphylococcus aureus } \\
\text { ATCC } 6538\end{array}$ & $\begin{array}{c}\text { Pseudomonas aeruginosa } \\
\text { ATCC } 9027\end{array}$ & $\begin{array}{c}\text { Candida albicans } \\
\text { ATCC } 885 / 653\end{array}$ \\
\hline \multicolumn{5}{|c|}{ Sample 1 without a preservative } \\
\hline $\begin{array}{l}\text { Microbial loading after } \\
\text { inoculation, lg CFU / ml }\end{array}$ & 5.6 & 5.7 & 5.7 & 5.4 \\
\hline 2 days & 1.40 & 2.0/2.27 & $2.0 / 2.35$ & 1.85 \\
\hline 7 days & 1.65 & 3.0/3.74 & 3.0/4.16 & 2.74 \\
\hline 14 days & $2.0 / 1.80$ & $\mathrm{HB}$ & $\mathrm{HB}$ & $2.0 / 3.5$ \\
\hline 28 days & $\mathrm{H} 3 / 1.95$ & $\mathrm{H} 3 / \mathrm{HB}$ & $\mathrm{H} 3 / \mathrm{HB}$ & $\mathrm{H} 3 / \mathrm{HB}$ \\
\hline \multicolumn{5}{|c|}{ Sample 2 with germaben } \\
\hline $\begin{array}{l}\text { Microbial loading after } \\
\text { inoculation, lg CFU / ml }\end{array}$ & 5,7 & 5,7 & 5,7 & 5,7 \\
\hline 2 days & 1.50 & $2.0 / 3.2$ & $2.0 / 2.84$ & 2.35 \\
\hline 7 days & 2.15 & $3.0 / \mathrm{HB}$ & $3.0 / 4.65$ & 3.96 \\
\hline 14 days & $2.0 / 2.90$ & $\mathrm{HB}$ & $\mathrm{HB}$ & $2.0 / \mathrm{HB}$ \\
\hline 28 days & $\mathrm{H} 3 / / \mathrm{HB}$ & $\mathrm{H} 3 / \mathrm{HB}$ & $\mathrm{H} 3 / \mathrm{HB}$ & $\mathrm{H} 3 / \mathrm{HB}$ \\
\hline \multicolumn{5}{|c|}{ Sample 3 with nipagin } \\
\hline $\begin{array}{l}\text { Microbial loading after } \\
\text { inoculation, lg CFU / ml }\end{array}$ & 5.6 & 5.4 & 5.7 & 5.6 \\
\hline 2 days & 1.62 & $2.0 / 2.85$ & $2.0 / 2.35$ & 2.48 \\
\hline 7 days & 1.90 & 3.0/HB & $3.0 / 4.60$ & 3.74 \\
\hline 14 days & $2.0 / 2.75$ & $\mathrm{HB}$ & $\mathrm{HB}$ & 2.0/4.40 \\
\hline 28 days & $\mathrm{H} 3 / / \mathrm{HB}$ & $\mathrm{H} 3 / \mathrm{HB}$ & $\mathrm{H} 3 / \mathrm{HB}$ & $\mathrm{H} 3 / \mathrm{HB}$ \\
\hline \multicolumn{5}{|c|}{ Sample 4 with euxyl K 100} \\
\hline $\begin{array}{l}\text { Microbial loading after } \\
\text { inoculation, lg CFU / ml }\end{array}$ & 5.6 & 5.65 & 5.74 & 5.65 \\
\hline 2 days & 1.60 & $2.0 / 2.26$ & $2.0 / 2.40$ & 2.0 \\
\hline 7 days & 1.84 & 3.0/4.65 & $3.0 / 4.50$ & 3.48 \\
\hline 14 days & $2.0 / 2.10$ & $\mathrm{HB}$ & $\mathrm{HB}$ & $2.0 / \mathrm{HB}$ \\
\hline 28 days & $\mathrm{H} 3 / \mathrm{HB}$ & $\mathrm{H} 3 / \mathrm{HB}$ & $\mathrm{H} 3 / \mathrm{HB}$ & $\mathrm{H} 3 / \mathrm{HB}$ \\
\hline \multicolumn{5}{|c|}{ Sample 5 with euxyl PE 9010} \\
\hline $\begin{array}{l}\text { Microbial loading after } \\
\text { inoculation, lg CFU / ml }\end{array}$ & 5.6 & 5.7 & 5.8 & 5.7 \\
\hline 2 days & 1.55 & $2.0 / 3.2$ & $2.0 / 2.9$ & 2.0 \\
\hline 7 days & 1.65 & $3.0 / 4.74$ & $3.0 / 4.05$ & 3.74 \\
\hline 14 days & $2.0 / 2.40$ & $\mathrm{HB}$ & $\mathrm{HB}$ & $2.0 / \mathrm{HB}$ \\
\hline 28 days & $\mathrm{H} 3 / / \mathrm{HB}$ & $\mathrm{H} 3 / \mathrm{HB}$ & $\mathrm{H} 3 / \mathrm{HB}$ & $\mathrm{H} 3 / \mathrm{HB}$ \\
\hline \multicolumn{5}{|c|}{ Sample 6 with sodium benzoate } \\
\hline $\begin{array}{l}\text { Microbial loading after } \\
\text { inoculation, lg CFU / ml }\end{array}$ & 5.6 & 5.6 & 5.7 & 5.5 \\
\hline 2 days & 1.40 & $2.0 / 3.3$ & 2.0/2.27 & 1.89 \\
\hline 7 days & 1.65 & $3.0 / \mathrm{HB}$ & $3.0 / 4.66$ & 3.54 \\
\hline 14 days & $2.0 / 2.95$ & $\mathrm{HB}$ & $\mathrm{HB}$ & $2.0 / 3.20$ \\
\hline 28 days & $\mathrm{H} 3 / \mathrm{HB}$ & $\mathrm{H} 3 / \mathrm{HB}$ & $\mathrm{H} 3 / \mathrm{HB}$ & $\mathrm{H} 3 / \mathrm{HB}$ \\
\hline
\end{tabular}

tively. Euxyl PE 9010 containing phenoxyethanol and ethylhexylglycerin is a fat-soluble preservative, therefore, its introduction requires more content of solubilizers, and it is economically impractical. Nipagin and germaben containing parabens require additional quali- tative and quantitative determination as a part of the product developed.

The purified water heated to the temperature of 90 $95^{\circ} \mathrm{C}$ was added to HEC to increase the speed of swelling and gel formation. To determine the temperature 
regimen of CPHFS introduction the thermogravimetric studies were performed that showed that the temperature of the gel base should not exceed $45^{\circ} \mathrm{C}$ (Fig. 5).

According to the physical and chemical properties of drugs and excipients the technological process of manufacturing the gel developed includes the following stages of operations: dissolution of essential oils in a solubilizer; obtaining of the gel base; obtaining of the gel and its homogenization; packaging and labelling of the final product.

\section{CONCLUSIONS}

1 . The use of $1.75 \%$ hydroxyethyl cellulose as a gelling agent that provides stability and the necessary structural and mechanical properties of the gel has been sub- stantiated experimentally. Microscopic studies have substantiated introduction of the solubilizer $-0.5 \%$ PEG-40 hydrogenated castor oil that promotes dissolution of the peppermint essential oil. To provide the moderate osmotic properties and prevent the gel drying $10 \%$ sorbitol has been introduced.

2. Microbiological studies have shown the necessity of using sodium benzoate as a preservative in the concentration of $0.3 \%$.

3 . The temperature regimen of cetylpyridinium hexafluorosilicate introduction in the composition of the gel base has been substantiated by thermogravimetric studies. The technology of a gel has been developed.

\section{REFERENCES}

1. Анісімов В.Ю., Гельмбольдт В.О., Половко Н.П. // Зб. наук. пр. співробітників НМАПО. - К., 2015. Bun. XXIV, кн. 1. - C. 458-461.

2. Державна фармакопея України / Державне підприємство «Науково-експертний фармакопейний центр». 1-е вид. - Х.: РІРЕГ, 2011. - Доп. 4. - 536 c.

3. Допоміжні речовини в технологї ліків: вплив на технологічні, споживчі, економічні характеристики $і$ терапевтичну ефективність: навч. посіб. для студ. вищ. фармач. навч. закл. / Авт.-уклад. І.М.Периев, Д.І.Дмитрієвський, В.Д.Рибачук та ін.; за ред. І.М.Перцеева. - Х.: Золоті сторінки, 2010. - 600 с.

4. Лебединець О.В. Розробка складу та технології стоматологічного гелю комплексної дї: дис. ... канд. фармац. наук: спец. 15.00.01 «Технологія ліків, організачія фармацевтичної справи та судова фармація» / О.В.Лебединецьь. - Х., 2012. - 146 c.

5. Ляпунов Н.А., Безугла Е.П., Дунай Е.В., Жемерова Е.Г. // Фармачия. - 2004. - №1. - С. 13-15.

6. Николаев А.И. Практическая терапевтическая стоматология / А.И.Николаев, Л.М.Цепов. - М.: МЕДпрессинформ, 2003. - 560 c.

7. Пат. 92599 Україна, МПК С 07 C 229/00/, С 01 В 33/00 Спосіб отримання гексафторосилікату ияетилпіридинію / В.О.Гельмбольдт, В.Ю.Анісімов, О.В.Продан. - № и 2014 02841. - Заявл.: 21.03.2014. Опубл.: 26.08.2014. - Бюл. №16.

8. Соловьева А.М. // Новое в стоматол. - 2011. - №3. - С. 36-37.

9. Ofner C.M. Gels and jellies / C.M.Ofner, C.M.Klech-Gelotte // Encyclopedia of Pharmaceutical Technology; ed. by J.Swarbrick, J.C.Boylan. 2-nd ed. - New York; Basel: Marsel Dekker, 2002. - Vol. 2. - P. 1327-1344.

10. Picout David R. // The Sci. World J. - 2003. - Vol. 24, №3. - P. 105-121.

\section{РОЗРОБКА СКЛАДУ ТА ТЕХНОЛОГІЇ КАРІЄСПРОФІЛАКТИЧНОГО ГЕЛЮ}

\section{В.Ю.Анісімов, В.О.Гельмбольдт, Н.П.Половко}

Ключові слова: карієспрофрілактичний гель; цетилпіридинію гексафрторосилікат; технологія гелів

Профрілактика карієсу передбачає ремінералізацію поверхні зуба препаратами кальцію та фросфору, однак більш ефективним є використання фрторовмісних засобів у фрормі крему, гелю та лаку. Метою роботи було обгрунтування складу та технології гелю карієспрофілактичної дії з цетилпіридинію гексафрторосилікатом. Експериментально обрано гелеутворювач - гідроксіетилцелюлозу, що забезпечує стабільність та необхідні структурно-механічні властивості гелю. В результаті мікроскопічних досліджень обрано солюбілізатор ПЕГ-40 гідрогенізовану рицинову олію в концентрації 0,5\%, яка сприяє розчиненню ефірної олії м'яти при збереженні прозорості гелю. Для забезпечення помірних осмотичних властивостей та попередження висихання гелю обгрунтовано використання 10\% сорбітолу. Мікробіологічні дослідження продемонстрували необхідність застосування в якості консерванту натрію бензоату в концентрації 0,3\%. Термогравіметричні дослідження обгрунтували температурний режим введення цетилпіридинію гексафоторосилікату до складу гелевої основи. Розроблено технологію гелю. 


\section{РАЗРАБОТКА СОСТАВА И ТЕХНОЛОГИИ КАРИЕСПРОФИЛАКТИЧЕСКОГО ГЕЛЯ}

\section{В.Ю.Анисимов, В.А.Гельмбольдт, Н.П.Половко}

Ключевые слова: кариеспрофилактический гель; цетилпиридиния гексафрторосиликат; технология гелей

Просрилактика кариеса предусматривает реминерализацию поверхности зуба препаратами кальция и фросфора, однако более эффрективным является использование фрторсодержащих средств в форме крема, геля и лака. Целью работы было обоснование состава и технологии геля кариеспрофилактического действия с иетилпиридиния гексафрторосиликатом. Экспериментально выбран гелеобразователь - гидроксиэтилцелюлоза, обеспечивающая стабильность и необходимые структурно-механические свойства геля. Микроскопическими исследованиями обосновано введение солюбилизатора ПЭГ-40 гидрогенизированного касторового масла в концентрации 0,5\%, которое способствует растворению эфрирного масла мяты при сохранении прозрачности геля. Для обеспечения умеренных осмотических свойств и предупреждения высыхания геля обосновано использование $10 \%$ сорбитола. Микробиологические исследования продемонстрировали необходимость применения в качестве консерванта натрия бензоата в концентрации 0,3\%. Термогравиметрические исследования обосновали температурный режим введения цетилпиридиния гексафрторосиликата в состав гелевой основы. Разработана технология геля. 